\title{
ВИКОНАННЯ ДЕРЖАВНОЮ ПРИКОРДОННОЮ СЛУЖБОЮ УКРАЇНИ ДОРУЧЕНЬ ПРАВООХОРОННИХ ОРГАНІВ ЯК СКЛАДНИК БОРОТЬБИ З ОРГАНІЗОВАНОЮ ЗЛОЧИННІСТЮ
}

у статmі розглядається нормативно-правове забезпечення виконання Державною прикордонною службою України доручень уповноважених державних органів як складника боротьби з організованою злочинністю. Наукове дослідження здійснене з використанням методів дедукції та індукції, аналізу та синтезу, які допомогли визначити логічну схему дослідження. Логіко-семантичний та догматичний методи застосовувались під час встановлення змісту правових норм та обсягу повноважень органів Державної прикордонної служби України. Системний метод допоміг з'ясувати структуру діяльності органів Державної прикордонної служби України щодо виконання доручень правоохоронних органів. Об'єктами досліӘження стали нормативно-правові акти, які регулюють діяльність Державної прикордонної служби України щодо виконання доручень правоохоронних органів та боротьби з організованою злочинністю.

На підставі вивчення норм національного законодавства встановлено, що в процесі охорони державного кордону України та здійснення прикордонного контролю персонал органів Державної прикордонної служби України поряд із виконанням оперативно-службових завдань бере участь у боротьбі з організованою злочинністю, зокрема під час виконання доручень уповноважених державних органів.

3'ясовано, що повноваження органів Державної прикордонної служби України щодо боротьби з організованою злочинністю реалізуються безпосередньо як на лінії державного кордону України, так і в межах контрольованих прикордонних районів.

На підставі проведеного дослідження можна зробити висновки, що під час виконання Державною прикордонною службою України доручень уповноважених державних органів можуть бути реалізовані такі складники боротьби з організованою злочинністю: отримання додаткової інформації про осіб, причетних до організованої злочинності (в окремих її проявах), контроль або недопущення перетинання ними в межах чинного законодавства державного кордону або лінії розмежування з тимчасово окупованою територією України, а в необхідних випадках і затримання злочинців.

Ключові слова: організованазлочинність, боротьба з організованою злочинністю, Державна прикордонна служба України, виконання доручень правоохоронних органів, прикордонні загони, органи охорони кордону.

Ляшук Р. М., Гетманюк С. П.

Liashuk R. M., Getmanyuk S. P. Execution by the State Border Guard Service of Ukraine of law enforcement orders as a component of the fight against organized crime

The article considers the regulatory and legal support for the implementation of the State Border Guard Service of Ukraine orders of law enforcement agencies as part of the fight against organized crime. The research was carried out using the methods of deduction and induction, analysis and synthesis, which helped to determine the structural and logical scheme of the study. Logical-semantic and dogmatic methods were used in establishing the content of legal norms and the scope of powers of the State Border Guard Service of Ukraine. The system method helped to clarify the structure of the activities of the State Border Guard Service of Ukraine to implement the instructions of law enforcement agencies. The objects of the study were the regulations governing the activities of the State Border Guard Service of Ukraine to implement the orders of law enforcement agencies and the fight against organized crime.

Based on the study of national legislation, it is established that guarding certain areas of the state border of Ukraine, the bodies of the State Border Guard Service of Ukraine participate in the fight against organized crime, in particular, during the execution of law enforcement orders.

It was found that the powers of the State Border Guard Service of Ukraine to combat organized crime are exercised at the state border of Ukraine and within the controlled border areas.

The study allowed us to conclude that during the implementation of the State Border Guard Service of Ukraine, the tasks of combating organized crime may be achieved as: obtaining additional information about persons involved in organized crime, preventing them from crossing the state border of Ukraine or the demarcation line, temporarily occupied territory of Ukraine, and in necessary cases detention of criminals.

Key words: organized crime, fight against organized crime, State Border Guard Service of Ukraine, execution of orders of law enforcement agencies, border detachments, border guards.

(с) Ляшук Р. М., Гетманюк С. П., 2020 
Постановка проблеми та іï актуальність. 3 огляду на те, що географічне положення нашої країни зумовлює проходження через її територію ключових коридорів транскордонної злочинності, проблема боротьби з організованою злочинністю для більшості іï регіонів залишається актуальною. Злочинні організації та угруповання, в тому числі і міжнародного масштабу продовжують контролювати значну частину тіньового капіталу та здійснюють протиправну діяльність, пов'язану з розкраданням бюджетних коштів, відмиванням одержаних злочинним шляхом доходів, наркобізнесом, торгівлею людьми, нелегальною міграцією, тощо.

Організована злочинність, як і будь-яка протиправна діяльність, характеризується складністю та багатогранністю економічних, корупційних та міжнародних зв'язків та процесів. Мета діяльності організованих злочинних угруповань зазвичай досягається шляхом вчинення як корисливо-насильницьких злочинів, так і злочинів проти національної безпеки держави. Нині Україна залишається об'єктом постійної зацікавленості міжнародних злочинних угруповань, зокрема у сферах незаконного переміщення через державний кордон зброї, наркотичних засобів та небезпечних речовин, торгівлі людьми, легалізації (відмивання) доходів. Разом із тим гібридна війна Російської Федерації проти України, глобальні соціально-економічні процеси міжнародного та світового масштабу, такі як урбанізація, міждержавна та міжрегіональна міграція, формування світового інформаційно-культурного простору $\epsilon$ одними 3 ключових та численних чинників, які $\epsilon$ векторами сприяння та рушійної сили організованої злочинності.

Боротьбу з організованою злочинністю здійснюють визначені законом суб'єкти. Одними з пріоритетних їхніх завдань $€$ пошук нових шляхів боротьби з організованою злочинністю відповідно до сучасних реалій та з урахуванням тенденцій розвитку суспільства і держави $[1$, п. 1].

У Законі України «Про організаційно-правові основи боротьби з організованою злочинністю» поняття організованої злочинності трактується як сукупність злочинів, що вчиняються у зв'язку зі створенням та діяльністю організованих злочинних угруповань [2, ст. 1].

Нині встановлення контролю над організованою злочинністю, ï локалізація, нейтралізація та ліквідація, усунення причин та передумов іiі існування $\epsilon$ головною метою боротьби з організованою злочинністю [2, ст. 2]. У повному обсязі виконання цього завдання не під силу жодному окремо взятому суб'єкту боротьби з організованою злочинністю.

До державних органів та інститутів, які певним чином причетні або беруть участь у боротьбі 3 організованою злочинністю, належить Державна прикордонна служба України (далі - ДПСУ) [2, ст. 5], яка $\epsilon$ правоохоронним органом спеціального призначення [3, ст. 6]. Однією із функцій ДПСУ $\epsilon$ участь у боротьбі з організованою злочинністю та протидія незаконній міграції на державному кордоні України та в межах контрольованих прикордонних районів [3, ст. 2].

Відповідно до визначених законом функцій, на персонал ДПСУ покладається низка функціональних обов' язків, зокрема:

- організація запобігання кримінальним правопорушенням, протидію яким законодавством зараховано до компетенції ДПСУ, їх виявлення та припинення;

розшук у пунктах пропуску через державний кордон та контрольних пунктах в'їзду-виїзду осіб, які переховуються від органів досудового розслідування та суду;

участь у межах своєї компетенції у взаємодії з органами Служби безпеки України, органами Національної поліції та іншими правоохоронними органами в боротьбі з тероризмом та виконання інших покладених на них завдань.

Важливим повноваженням ДПСУ, яке спрямоване на боротьбу з організованою злочинністю, $\epsilon$ запобігання та недопущення, згідно з дорученнями уповноважених державних органів, перетинання державного кордону України особами, яких тимчасово обмежено в праві виїзду з України або яким не дозволяється в'їзд в Україну [3, ст. 19].

Аналіз останніх досліджень $\mathbf{i}$ публікацій. Питання правового регулювання діяльності щодо боротьби з організованою злочинністю досліджували вітчизняні вчені В.Б. Авер'янов, О.М. Бандурка, В.Л. Грохольський, О.М. Джужа, Р.А. Калюжний, О.Г. Кальман, В.К. Колпаков, Н.Р. Нижник, Р.С. Орловський, В.В. Половніков, С.І. Халимон, В.О. Шамрай, О.Н. Ярмиш та інші.

Метою статті $\epsilon$ вивчення питання виконання Державною прикордонною службою України доручень уповноважених державних органів як складника боротьби з організованою злочинністю комплексно не проводилось, що і зумовлює потребу додаткових досліджень у цьому напрямі.

Виклад основного матеріалу. Для боротьби з організованою злочинністю, як один із суб'єктів боротьби з протиправною діяльністю, ДПСУ 
наділена низкою повноважень, серед яких і право здійснювати згідно з дорученнями уповноважених державних органів України затримання в пунктах пропуску осіб, які прямують через державний кордон або лінію розмежування з тимчасово окупованою територією України, та розшукуються за підозрою у вчиненні злочину, переховуються від органів досудового розслідування та суду, ухиляються від відбуття кримінального покарання та в інших випадках, передбачених законодавством України [3, ст. 20].

Розглянемо детальніше участь ДПСУ у боротьбі з організованою злочинністю шляхом виконання доручень уповноважених державних органів.

Доручення уповноважених державних органів це письмовий припис уповноважених державних органів ДПСУ щодо проведення щодо окремих осіб (у визначених законодавством випадках та спосіб) певних процесуальних, оперативних або спеціальних заходів [4, п. 1].

Доручення ДПСУ надаються уповноваженими державними органами відповідно до їхньої компетенції та за наявності підстав, визначених законом [5, п. 3].

Уповноважені державні органи мають право надавати ДПСУ доручення щодо:

заборони в'їзду в Україну іноземців та осіб без громадянства протягом строку, встановленого уповноваженим державним органом;

заборони виїзду з України осіб, яких за рішенням слідчого судді, суду тимчасово обмежено у праві виїзду з України, у тому числі тих, до яких застосовано запобіжний захід, передбачений Кримінальним процесуальним кодексом України, умовами якого передбачено таке обмеження;

розшуку в пунктах пропуску через державний кордон осіб, оголошених у розшук відповідно до Кримінального процесуального кодексу України;

- інформування про факт перетинання державного кордону особами, стосовно яких уповноваженими державними органами проводяться оперативно-розшукові, контррозвідувальні, розвідувальні заходи або слідчі (розшукові) дії та негласні слідчі (розшукові) дії в кримінальному провадженні, заходи з протидії порушенням митних правил, а також прийнято рішення про добровільне чи примусове повернення в країну походження або третю країну;

огляду (із залученням у разі потреби службових осіб митної служби, що використовують власні технічні та спеціальні засоби) транспортних засобів, на яких подорожують особи, та ван- тажів, що ними переміщуються через державний кордон, з метою недопущення незаконного перетинання його особами, а також незаконного переміщення предметів і речовин, які заборонені до вивезення і ввезення в Україну або щодо яких встановлено спеціальний порядок переміщення через державний кордон; виявлення викрадених транспортних засобів;

- додаткового вивчення питання щодо наявності законних підстав для перетинання державного кордону особами [4, п. 5].

Доручення оформляються за підписом Голови Національної поліції, Голови СБУ, Голови Служби зовнішньої розвідки, начальника Управління державної охорони, Міністра юстиції, Генерального прокурора, начальника Головного управління розвідки Міноборони, Директора Національного антикорупційного бюро, Директора Державного бюро розслідувань або їхніх заступників, уповноважених ними керівників підрозділів центрального апарату цих органів [5, п. 6].

У дорученні його ініціатором зазначаються такі відомості про особу: громадянство (підданство); прізвище, ім'я (імена) та по батькові (за наявності) особи в називному відмінку (для громадян України - українською мовою, для іноземців та осіб без громадянства - латиницею); дата народження (день, місяць, рік); стать; місце проживання; серія та номер паспортного документа, коли і ким виданий [5, п. 8].

У разі виникнення потреби в терміновому виконанні доручення його зміст може передаватися телеграмою або телефаксом 3 обов'язковим подальшим поданням протягом п'яти діб органу ДПСУ оригіналу доручення. Усі доручення беруться ним на контроль не пізніше наступного дня після їх надходження та на строк, зазначений у дорученні [5, п. 11-13].

Орган ДПСУ не приймає доручення до виконання, якщо:

- воно не стосується передбачених законом питань;

- його виконання призведе до порушення вимог законодавства та прав людини;

до доручення про заборону в'їзду в Україну іноземців та осіб без громадянства не додано копї відповідної постанови, винесеної посадовою особою уповноваженого державного органу;

- до доручення про заборону виїзду з України не додано копії рішення слідчого судді, суду;

до доручення про розшук у пунктах пропуску осіб, оголошених у розшук відповідно до Кримінального процесуального кодексу України, не 
додано копї̈ ухвали суду чи постанови слідчого або прокурора;

відомості про особу не зазначені в повному обсязі;

не зазначено спосіб інформування уповноваженого державного органу чи його посадової особи про хід виконання доручення;

доручення надійшло за підписом посадової особи, яка не вповноважена надавати доручення [5, п. 16].

Виконання доручень здійснюється в пунктах пропуску через державний кордон уповноваженими службовими особами ДПСУ під час виконання процедури перевірки документів на право в’їзду або виїзду з України. Відповідно до міжнародних договорів України із суміжними державами про здійснення спільного прикордонного контролю, в пунктах пропуску через державний кордон ДПСУ може проводити із прикордонними службами таких держав обмін інформацією про осіб, стосовно яких надано доручення щодо обмеження їхнього права виїзду за межі держави проживання (перебування) [5, п. 17, 18].

Залежно від виду доручень під час уведення інформації до відповідної оперативної бази даних системи «Гарт-1» кожному з них присвоюється відповідний індекс [4, п. 5]. Також визначений порядок дій посадових осіб органів та підрозділів охорони державного кордону в разі збігу інформації про особу, яка перетинає державний кордон або в'їжджає на тимчасово окуповану територію України, з інформацією, що зберігається в оперативних базах даних системи «Гарт-1» за кожним індексом [4]. 3 огляду на те, що кожне доручення стосується насамперед особи, можливо уніфікувати загальний порядок дій уповноважених службових осіб ДПСУ у разі виявлення в пунктах пропуску через державний кордон осіб, стосовно яких надано доручення уповноважених державних органів, тоді його можна трактувати таким чином:

1) у разі збігу інформації про особу, яка перетинає державний кордон або лінію розмежування 3 тимчасово окупованою територією України, інспектор прикордонної служби, що здійснює перевірку паспортних документів, доповідає старшому зміни прикордонних нарядів або старшому прикордонних нарядів у пункті пропуску про виявлення особи, щодо якої $\epsilon$ доручення правоохоронних органів;

2) старший прикордонних нарядів повторно перевіряє наявність в оперативній базі даних доручення щодо виявленої особи, невідкладно інфор- мує про це чергового Головного центру та виконує дії, передбачені дорученням (інформування про факт перетинання державного кордону, заборона в'їду в Україну, непропуск особи через державний кордон України, скасування візи, затримання особи, додатковий огляд чи вивчення питання щодо наявності законних підстав для перетинання державного кордону особами), про прийняте рішення та вжиті заходи доповідає начальникові зміни відділу управління службою органу охорони державного кордону;

3) начальник відділу управління службою про факт виконання доручення доповідає начальникові зміни відділу управління службою регіонального управління i начальникові органу охорони державного кордону, а в необхідних випадках, але до закінчення процедури прикордонного контролю, інформує по телефону ініціатора доручення;

4) начальник зміни відділу управління службою регіонального управління доповідає про факт виконання доручення начальникові зміни Головного центру управління службою Адміністрації ДПСУ і начальникові штабу регіонального управління;

5) інформація про виконання доручень надається на письмову вимогу суду, прокуратури, органів досудового розслідування та інших органів державної влади (посадових осіб) у зв'язку зі здійсненням ними повноважень, визначених законодавством України [4, п. 1-6].

3 огляду на вищезазначене, виконання персоналом ДПСУ доручень уповноважених державних органів у контексті протидії організованій злочинності дає змогу визначити низку правоохоронних завдань, результатом вирішення яких буде отримання додаткової (випереджувальної) інформації про осіб, котрі причетні до організованої злочинності, недопущення перетинання ними кордону або лінії розмежування з тимчасово окупованою територією України та (або) затримання.

Висновки. Отже, діяльність органів ДПСУ щодо боротьби з організованою злочинністю значною мірою забезпечується шляхом виконання доручень уповноважених державних органів. Зазначена правоохоронна функція дПСУ реалізується в процесі здійснення прикордонного контролю в пунктах пропуску через державний кордон або заходів контролю в'їзду-виїзду осіб, транспортних засобів та товарів у контрольних пунктах в'їзду-виїзду.

Важливим аспектом $€$ і той факт, що виконання доручень уповноважених державних органів від- 
повідно до п. 4 ст. 2 [6] є складником прикордонного контролю, який своєю чергою, разом із участю у боротьбі з організованою злочинністю та протидією незаконній міграції на державному кордоні України та в межах контрольованих прикордонних районів, відповідно до ст. 2 [3] належить до функцій ДПСУ. Підсумовуючи вищевикладене, можна дійти висновку, що саме ДПСУ наділена можливостями та реалізує повноваження щодо контролю осіб, які перетинають державний кордон України, чого не здійснюють інші правоохоронні органи, причому їі функція щодо боротьби з організованою злочинністю реалізується за рахунок іншої, а саме здійснення в установленому порядку прикордонного контролю і пропуску через державний кордон України та до тимчасово окупованої території. Своєю чергою прикордонний контроль, відповідно до ст. 5 [6], може здійснюватись як у пунктах пропуску, так і поза ними, підтверджуючи можливість виконання повноважень органів ДПСУ на територіях із надзвичайним адміністративно-правовим режимом - на державному кордоні України та в межах контрольованих прикордонних районів.

Зусилля подальших наукових досліджень у цій сфері варто зосередити на правовому регулюванні взаємодії органів ДПСУ з іншими правоохоронними органами з питань протидії організованій злочинності.

\section{Література}

1. Про Концепцію державної політики у сфері боротьби з організованою злочинністю : Указ Президента України від 21.10.2011 р. № 1000/2011. URL: https://zakon.rada.gov.ua/laws/ show/1000/2011\#Text (дата звернення: 12.07.2020).

2. Про організаційно-правові основи боротьби з організованою злочинністю : Закон України від 30 червня 1993 р. № 3341-XII. URL: https://zakon. rada.gov.ua/laws/show/3341-12\#Text (дата звернення: 05.08.2020).
Протидія злочинності: проблеми практики та науково-методичне забезпечення

3. Про Державну прикордонну службу України : Закон України від 3 квітня 2003 р. Відомості Верховної Ради України. 2003. № 27. Ст. 208.

4. Про затвердження Порядку дій уповноважених службових осіб Державної прикордонної служби України в разі виявлення в пунктах пропуску через державний кордон України та контрольних пунктах в'їзду на тимчасово окуповану територію України та виїзду з неї осіб, стосовно яких надано доручення, та порядку взаємодії органів охорони державного кордону з уповноваженими державними органами, які надали доручення: наказ Міністерства внутрішніх справ України від 23.06.2017 р. № 535. URL: https:// zakon.rada.gov.ua/laws/show/z1091-17\#Text (дата звернення: 12.05.2020).

5. Про затвердження Порядку надання Державній прикордонній службі та виконання нею доручень уповноважених державних органів щодо осіб, які перетинають державний кордон, та визнання такими, що втратили чинність, деяких постанов Кабінету Міністрів України : Постанова Кабінету Міністрів України від 17.04.2013 р. № 280. URL: https: / zakon. rada.gov.ua/laws/show/280-2013-\%D0\%BF\#Text (дата звернення: 13.05.2020).

6. Про прикордонний контроль : Закон України від 5 листопада 2009 p. URL: https://zakon.rada. gov.ua/laws/show/1710-17\#Text (дата звернення: 13.05.2020).

Ляшук Р. М., доктор юридичних наук, доцент, начальник кафедри теорії, історії держави і права та приватноправових дисциплін Національної академії Державної прикордонної служби України імені Богдана Хмельницького

Гетманюк С. П., кандидат військових наук, доцент, викладач кафедри прикордонного контролю Національної академії Державної прикордонної служби України імені Богдана Хмельницького 